\title{
PENGEMBANGAN MODEL PERMAINAN SEPATU BATOK UNTUK PEMBELAJARANSEPAK BOLA PENDIDIKAN JASMANI, OLAHRAGA DAN KESEHATAN SISWASEKOLAH DASAR
}

\author{
Rachmi Marsheilla Aguss', Eko Bagus Fahrizqi ${ }^{2}$
}

Universitas Teknokrat Indonesia

\begin{abstract}
ABSTRAK
Penelitian ini bertujuan menghasilkan model permainan tradisional sepatu batok digunakan sebagai panduan: meningkatkan kualitas pembelajaran, mengetahui efektivitas permainan sepatu batok untuk pembelajaran penjasorkes SD, mengetahui keterterimaan permainan sepatu batok. Metode penelitian menggunakan pengembangan produk model permainan sepatu batok siswa SD dilakukan dengan 6 tahapan. Teknik pengumpulan data menggunakan observasi dan kuisioner, teknik analisis data persentase, pengujian validitas dan reliabilitas menggunakan program SPSS 20. Subjek penelitian siswa SD berjumlah 70 orang dan guru 4 orang. Hasil penelitian berupa produk permainan tradisional sepatu batok yang dapat digunakan sebagai media pembelajaran penjasorkes, berdasarkan uji skala besar menunjukkan: koefisien reliabilitas 70 siswa responden yaitu 0,589. Guttman Split-Half Coefficient untuk 4 guru responden yaitu 0,956. Dapat disimpulkan hasil reliabilitas untuk respon guru dikatakan reliabel karena $r$ hitung lebih besar dari $r$ tabel dengan taraf signifikan 5\%. Data responden siswa sebagai penguat dalam penilaian yang diambil dengan indikator kognitif $91,42 \%$, indikator psikomotor $97,5 \%$, indikator afektif $96,25 \%$, kenaikan jumlah denyut nadi pembelajaran laki-laki $69,16 \%$ sedangkan kenaikan jumlah denyut nadi pembelajaran perempuan $68,60 \%$. Kesimpulan, pengembangan permainan sepatu batok untuk pembelajaran Penjasorkes di SD menghasilkan produk efektif untuk meningkatkan pembelajaran sepak bola siswa. Disarankan bagi guru untuk dapat menggunakan model permainan sepatu batok sebagai bahan ajar alternatif pembelajaran penjasorkes.
\end{abstract}

Kata kunci: pengembangan, permainan tradisional, sepatu batok

\begin{abstract}
The aim of this research is to produce a traditional model of shell shoes used as a guide: improving the quality of learning, knowing the effectiveness of the game of shell shoes for elementary school physical education learning, knowing the acceptability of the game of shell shoes. The research method uses the development of a model of elementary school student shell shoes game model carried out with 6 stages. Data collection techniques used observation and questionnaires, percentage data analysis techniques, testing the validity and reliability using SPSS 20 . The research subjects consisted of 70 elementary school students and 4 teachers. The results of research in the form of a traditional game of shell shoes that can be used as a learning medium for physical education, based on a large-scale test shows: the reliability coefficient of 70 student respondents is 0.589. Guttman Split-Half Coefficient for 4 teacher respondents is 0.956 . It can be concluded that the reliability results for teacher responses are said to be reliable
\end{abstract}


because $r$ counts are greater than $r$ tables with a significant level of $5 \%$. Data of student respondents as an amplifier in the assessment taken with cognitive indicators $91.42 \%$, psychomotor indicators $97.5 \%$, affective indicators $96.25 \%$, an increase in the number of pulses of male learning $69.16 \%$ while an increase in the number of pulses of female learning $68.60 \%$. In conclusion, the development of the game of shell shoes for learning Penjasorkes in elementary schools produces effective products to improve student soccer learning. It is recommended for teachers to be able to use the model of shell shoes as an alternative teaching material for Physical Education learning.

Keywords: Development, traditional games, shell shoes

\section{PENDAHULUAN}

Pendidikan jasmani, olahraga dan kesehatan pada hakekatnya adalah "suatu proses pendidikan yang memanfaatkan aktivitas fisik untuk menghasilkan perubahan bersifat menyeluruh (holistic) dalam kualitas individu baik dalam hal fisik, mental, serta emosional" (Agus Mahendra, 2003). Pembelajaran pendidikan jasmani, olahraga dan kesehatan memiliki kepentingan yang relatif sama dengan program pendidikan lainnya dalam hal domain pembelajaran, yaitu sama-sama mengembangkan tiga domain utama: psikomotor, afektif, dan kognitif. Namun demikian, ada satu kekhasan dan keunikan dari pendidikan jasmani, olahraga dan kesehatan yang tidak dimiliki oleh program pendidikan lain, yaitu dalam hal pengembangan wilayah psikomotor, yang biasanya dikaitkan dengan tujuan mengembangkan kebugaran jasmani anak dan pencapaian keterampilan geraknya. Di samping keunikan tersebut, bahwa pendidikan jasmani, olahraga dan kesehatan tetap meningkatkan aspek-aspek yang berada dalam wilayah afektif dan kognitif.

Pendidikan tidak lengkap tanpa pendidikan jasmani, dan tidak ada pendidikan jasmani tanpa media gerak. Gerak sebagai aktivitas jasmani merupakan dasar alami bagi manusia untuk belajar mengenal dunia dan dirinya sendiri. Oleh karena itu, sebagai salah satu komponen pendidikan yang wajib diajarkan di sekolah, pendidikan jasmani memiliki peran yang sangat strategis dalam pembentukan manusia seutuhnya (Toho Cholik Muthohir, 2004).

Pendidikan Jasmani, Olahraga, dan Kesehatan (Penjasorkes) merupakan bagian integral dari pendidikan secara keseluruhan, bertujuan untuk mengembangkan aspek kebugaran jasmani, keterampilan gerak, keterampilan berfikir kritis, keterampilan sosial, penalaran, stabilitas emosional, tindakan moral, aspek pola hidup sehat dan 
pengenalan lingkungan bersih melalui aktivitas jasmani, olahraga dan kesehatan terpilih yang direncanakan secara sistematis dalam rangka mencapai tujuan pendidikan nasional (Depdiknas, 2006).

Tujuan Penjasorkes dalam Kurikulum Satuan Pendidikan (KTSP), salah satunya yaitu meletakkan landasan karakter moral yang kuat melalui internalisasi nilai-nilai yang terkandung di dalam Penjasorkes. Upaya mensegarkan fisik dan mental khususnya nilai-nilai karakter dalam olahraga menjadi bagian yang tidak terpisahkan dalam Penjasorkes, artinya memasukkan nilai-nilai dalam rangka meletakkan landasan karakter moral yang kuat juga sama pentingnya menyegarkan mental dan itu dilakukan melalui kegiatan bermain melalui suatu permainan dan olahraga (Toho Cholik M, dkk, 2011).

Permainan bola besar yang dimaksud disini adalah pembelajaran permainan sepak bola. Permainan bola besar merupakan permainan yang suka dimainkan dengan anak-anak dimainkan dengan cara kompetisi, permainan bola besar selain mengembangkan kegiatan bermain para siswa, juga didalam permainan itu sendiri terdapat nilai-nilai untuk mengembangkan kepribadian.Sepak bola sebagai salah satu materi permainan bola besar nantinya akan diterapkan dalam proses pembelajaran penjasorkes, akan tetapi dalam bentuk permainannya akan dikemas yang sifatnya meminimalkan hal yang sedemikian rupa baik dalam sarana prasarana maupun lapangan yang akan dipakai. Bangsa Indonesia dikenal dengan keanekaragaman suku bangsa dan berbagai latar belakang kebudayaan yang tumbuh dan berkembang sebagai hasil adaptasi terhadap lingkungan alam dan sosial dalam melangsungkan kehidupannya. Sejak berabad-abad yang lampau kebudayaan daerah/suku-suku bangsa yang ada di kepulauan nusantara ini memiliki corak yang khas dan menjadi identitas serta digunakan sebagai pedoman, arah dan tujuan kehidupan masyarakat pendukungnya.

Permainan tradisional adalah sebagian bentuk kehidupan yang dilalui oleh nenek moyang kita. Hal utama yang menjamin permainan tradisional pada masa lalu adalah keseragaman cara hidup nenek moyang kita saat itu. Permainan tradisional juga dikenali sebagai permainan rakyat. Ada di antara permainan ini yang sekarang tidak dimainkan lagi, bahkan dilupakan. Pada dasarnya permainan tradisional memiliki cukup banyak keunggulan yang tidak didapat pada permainan modern, seperti tumbuhnya 
rasa solidaritas dan kesetiakawanan, rasa empati kepada sesama, keakraban dengan alam dan selalu menjunjung nilai-nilai sportifitas. Selain itu sisi positif lainnya yang dapat diperoleh dari aneka permainan tradisional adalah memungkinkan timbulnya inisiatif, kreatifitas anak untuk menciptakan dan inovasi untuk memproduksi sendiri.

Punahnya permainan tradisional disebabkan oleh beberapa faktor yang mempengaruhi diantaranya pengaruh teknologi, kemajuan teknologi terutama dalam bidang permainan anak-anak, perdagangan bebas, dan terbatasnya fasilitas yang ada dan lingkungan yang mendukung terlaksananya permainan tradisional. Pengaruh teknologi yang menjadi pendukung perkembangan globalisasi ini juga menjadi faktor pendorong hilangnya budaya kita sendiri. Banyaknya pilihan permainan di era modern membuat permainan tradisional hilang ditelan zaman. Kenyataan nya sebagian besar anak-anak atau peserta didik tidak mengetahui jenis permainan tradisional dan bahkan tidak tahu cara memainkannya serta aturan-aturannya, khususnya didaerah tempat tinggal mereka masing-masing. Faktor lainnya juga terletak pada cara mengajar seorang guru, kenyataan dilapangan dalam mengajar, guru masih kurang paham dengan tujuan pembelajaran penjasorkes yang mengakibatkan peserta didik bermalasmalasan dalam melakukan kegiatan fisik, beberapa peserta didik merasa bosan karena pembelajaran yang monoton dalam proses pembelajaran pendidikan jasmani, olahraga dan kesehatan.

Hal ini dapat kita lihat pada kenyataan, bahwa sebagian besar dari jenis-jenis permainan tradisonal daerah Lampung yang merupakan salah satu warisan budaya nenek moyang, terdesak oleh jenis-jenis permainan yang berasal dari luar seperti: permainan catur, bridge, remi, domino, dan sebagainya. Yang dimaksudkan dengan permainan anak-anak daerah Lampung dalam rangka inventarisasi adalah segala kegiatan jasmani yang dilakukan secara tertib dan mempunyai pola oleh para pendukungnya dan merupakan khasanah budaya yang mereka peroleh dari generasi terdahulu dilingkungan masyarakat daerah Lampung (Depdikbud, 1982).

Sepatu batok merupakan salah satu bentuk permainan tradisional yang biasa dimainkan oleh minimal 4 orang anak-anak, yang berusia sekitar 10-14 tahun, jika makin banyak peserta permainan maka akan semakin meriah. Permainan ini boleh dilakukan oleh anak-anak dari segala lapisan masyarakat. Peralatan yang digunakan 
dalam permainan yaitu sepotong batok kelapa dipakai sebagai sepatu dan tali yang panjangnya sekitar 1 meter.

Permainan sepatu batok ini tidak digunakan dalam proses pembelajaran penjasorkes untuk meningkatkan kemampuan, keterampilan gerak, dan keseimbangan yang sangat dibutuhkan bagi siswa. Pelaksanaan permainan sepatu batok akan dimainkan dalam bentuk permainan dengan unsur kompetisi sebagai bagian utama dari pembelajaran penjasorkes dengan tidak menghilangkan permainan aslinya secara teknis.

Berdasarkan hasil observasi yang dilakukan di Sekolah Dasar, diperoleh data tentang pelaksanaan pembelajaran sepak bola, materi pembelajaran sepak bola, dan ketersediaan sarana dan prasarana. Hasil pengamatan melalui observasi yaitu sebagian peserta didik merasa bosan, bermalas-malasan dan tidak bersemangat, inovatif dan kreatif dalam materi pembelajaran dan proses pembelajaran pendidikan jasmani, olahraga dan kesehatan sangat kurang sehingga tampak monoton, peran guru masih mendominasi aktivitas pembelajaran sehingga peserta didik kurang aktif memberikan umpan balik dan kurang memberikan pertanyaan-pertanyaan untuk menggali ide-ide yang sudah terkonstruk dalam pikiran peserta didik dan keberhasilan belajar peserta didik hanya dilihat pada hasil akhir tanpa memperhatikan proses pembelajaran sehingga hasil belajar paserta didik kurang dan belum mencapai hasil maksimal, dalam pelaksanaan pembelajaran sepak bola di sekolah masih kurang variasi pembelajaran penjasorkes yang dilakukan oleh guru disekolah.

Berdasarkan keterangan diatas dapat disimpulkan bahwa proses pembelajaran pendidikan jasmani, olahraga dan kesehatan di Sekolah Dasar terlaksana dengan menggunakan sarana dan prasaran yang dimiliki sekolah namun dalam proses pembelajaran tersebut belum maksimal sesuai dengan tujuan pembelajaran pendidikan jasmani, olahraga dan kesehatan. Permasalahan selanjutnya adalah minimnya upaya guru penjasorkes di Sekolah Dasar untuk menyusun, membuat materi penjasorkes yang baik, menarik dan inovatif. Hal ini menjadi permasalahan klasik, dan perlu upaya pemecahan yang bersifat dorongan serta motivasi dari berbagai pihak. Tidak ada salahnya apabila guru mencoba untuk sesuatu yang baru dengan menyusun, membuat permainan sepak bola yang sederhana namun menarik yang memenuhi kriteria perkembangan dan pertumbuhan peserta didik dan didalamnya menbuat unsur nilai 
yang dapat meningkatkan kognitif, afektif, dan psikomotorik bahkan pendidikan karakter peserta didik.

Pelaksanaan pembelajaran pendidikan jasmani, olahraga dan kesehatan pada permainan sepak bola di sekolah dasar belum dapat dilaksanakan secara optimal berkaitan dengan kurang beragamnya keterampilan gerak yang diberikan guru dan yang dapat dipelajari oleh peserta didik, kurang mendukungnya sarana dan prasarana yang memadai, peserta didik terkadang tidak memperhatikan guru saat menjelaskan pembelajaran sepak bola, kurangnya faktor perencanaan materi dalam pembelajaran penjasorkes. Disamping minimnya pengetahuan guru tentang perkembangan model pembelajaran khususnya yang terkait dengan pembelajaran penjasorkes. Tentu hal tersebut akan berdampak terhadap hasil belajar baik yang berhubungan dengan gerak dasar maupun hasil belajar.

Oleh karena itu perlu adanya sebuah pemecahan masalah yang perlu dilakukan. Kemajuan dibidang IPTEK pembelajaran saat ini sangat berkembang dengan pesat, berbagai model pembelajaran muncul sebagai alternatif pemecahan masalah pembelajaran saat ini yang belum maksimal. Terdapat berbagai model pendekatan pembelajaran yang menggunakan permainan sebagai mediasinya. Diharapkan dengan terlaksananya pembelajaran penjasorkes melalui permainan sepatu batok untuk pembelajaran sepak bola di Sekolah Dasar maka akan semakin banyak bentuk-bentuk permainan sehingga dapat menjadi salah satu sarana yang dapat dimafaatkan untuk mengembangkan pertumbuhan fisik dan perkembangan mental peserta didik seutuhnya dan terwujud pembelajaran yang bermakna. Artinya, peserta didik mampu membangun fisik dan mentalnya dengan belajar sambil bermain karena dengan permainan akan terbangun suasana yang lepas, bebas, menyenangkan dan atraktif serta memberi makna dalam belajar peserta didik.

\section{METODE}

Penelitian ini menggunakan metode penelitian dan pengembangan (research and development). Penelitian ini bertujuan untuk menghasilkan produk berupa bentuk permainan tradisional sepatu batok untuk pembelajaran sepak bola sekolah dasar. Menurut Brog dan Gall dalam Wasis D. Dwiyogo (2004) penelitian dan pengembangan merupakan metode atau cara yang digunakan untuk mengembangkan atau memvalidasi produk-produk yang digunakan dlam penelitian dan pembelajaran. 
Peneliti mengembangkan permainan sepatu batok untuk pembelajaran sepak bola di sekolah dasar disesuaikan dengan pertimbangan keadaan lapangan, keterbatasan waktu, tenaga, dan biaya sehingga tidak mengambil subyek yang besar. Langkah-langkah yang digunakan peneliti untuk pembelajaran sepak bola dalam permainan bola besar sebagai berikut:

1. Melakukan penelitian pendahuluan dan pengumpulan informasi. Termasuk observasi lapangan dan kajian pustaka

2. Mengembangkan bentuk produk awal (berupa bentuk pembelajaran sepak bola di lingkungan sekolah dasar seadanya)

3. Evaluasi para ahli dengan menggunakan satu ahli penjas dan dua ahli pembelajaran, serta ujicoba kalompok kecil, dengan menggunakan kuisioner dan konsultasi serta evaluasi yang kemudian di analisis

4. Revisi produk pertama. Revisi ini digunakan untk perbaikan terhadap produk awal yang dibuat oleh peneliti

5. Uji lapangan

6. Revisi produk akhir yang dilakukan berdasarkan hasil uji lapangan

7. Hasil akhir model permainan sepatu batok untuk pembelajaran sepak bola yang dihasilkan melalui revisi uji lapangan

8.

\section{Prosedur Pengembangan}

Prosedur atau langkah-langkah penelitian dan pengembangan tidak harus menggunakan langkah-langkah baku yang harus diikuti, tapi setiap pengembangan dapat memilih dan menentukan langkah yang paling tepat bagi penelitianya berdasarkan kondisi dan kendala yang dihadapinya (Wasis D. Dwiyogo, 2004). Berdasarkan pendapat tersebut maka prosedur yang digunakan dalam pengembangan model permainan sepatu batok untuk pembelajaran sepak bola siswa sd ini meliputi lima tahap utama, yaitu 1) Pengembangan penelitian deskriftip dan survei, 2) Penyusunan desain produk awal, 3), Validasi produk ahli, 4) Uji coba skala kecil, 5) Uji coba skala besar, 6) Penerapan model. 


\section{Instrumen pengambilan produk}

Instrumen yang digunakan dalam pengembangan produk berupa wawancara, observasi, kuisioner, dokumnetasi, denyut nadi, dan game peserta didik dalam bermain. Wawancara digunakan untuk mencari dan mengumpulkan informasi secara sistematis dan terarah dari para ahli dan nara sumber. Observasi digunakan untuk mengetahui keadaan sarana dan prasarana serta pelaksanaan proses pembelajaran sepak bola disekolah. Kuisioner digunakan untuk mendapatkan informasi dari para dosen (ahli penjas) dan guru Penjasorkes (ahli pembelajaran) untuk memberikan masukan dan saran tentang produk yang dihasilkan untuk mengetahui kualitas produk. Kuisioner yang digunakan oleh peserta didik berupa sejumlah pertanyaan yang harus dijawab oleh peserta didik dengan alternatif jawaban untuk mengetahui keterimaan produk. Kuisioner yang digunakan ahli berupa sejumlah aspek yang harus dinilai kelayakannya.

Dokumentasi digunakan untuk mengetahui latar belakang pendidikan dan keterampilan peserta didik dan sebagai bukti nyata mengenai suatu kegiatan. Denyut nadi digunakan sebagai indikasi tingkat keaktifan peserta didik selama pembelajaran permainan bola besar khususnya permainan sepak bola selama mengikuti proses pembelajaran.Butir yang digunakan dalam kuisioner meliputi kualitas model permainan sepatu batok, serta komentar dan saran umum jika ada. Rentangan penilaian mulai dari sangat baik sampai dengan sangat kurang.

Pengukuran tingkat kemampuan peserta didik baik kognitif, afektif, dan psikomotor dilakukan dengan pemberian kuisioner dan pengamatan unjuk kerja. Kuisioner untuk peserta didik berupa sejumlah pertanyaan untuk mengukur kemampuan kognitif (kualitas berfikir), kemampuan afektif (kualitas sikap), dan kemampuan psikomotor (kualitas gerak).

Spesifikasi instrumen terdiri dari tujuan dan kisi-kisi instrument, terdapat 3 aspek dalam penelitian ini yaitu kognitif alat ukur menggunakan kuisioner berupa soal-soal yang berkaitan dengan permainan sepatu batok, sedangkan afektif dan psikomotor menggunakan rubrik penilaian yang dinilai oleh guru.

\section{HASIL PENELITIAN}

Berdasarkan penentuan reliabilitas keterterimaan produk siswa untuk penelitian ini maka diperoleh data hasil perhitungan korelasi dari 10 butir soal, koefisien reliabilitas 
menggunakan Guttman Split-Half Coefficient untuk 70 siswa sebagai responden yaitu 0,589. Dapat disimpulkan hasil reliabilitas untuk respon siswa dikatakan reliabel karena rhitung lebih besar dari $r$ tabel yaitu 0,235 dengan taraf signifikan $5 \%$. Jumlah soal yang valid yaitu 8 soal, sedangkan yang tidak valid 2 soal (soal 9, 10) dengan rhitung terendah yaitu 0.060. Sesuai kriteria reliabilitas, maka dapat disimpulkan bahwa data butir soal yang valid mempunyai reliabilitas tinggi.

Berdasarkan penentuan reliabilitas keterterimaan produk guru untuk penelitian ini makadiperoleh data hasil perhitungan korelasi dari 20 butir soal, koefisien reliabilitas menggunakan Guttman Split-Half Coefficientuntuk 4 guru sebagai responden yaitu 0,956. Dapat disimpulkan hasil reliabilitas untuk respon siswa dikatakan reliabel karena rhitung lebih besar dari $r$ tabel yaitu 0,950 dengan taraf signifikan $5 \%$. Jumlah soal yang valid yaitu 16 soal, sedangkan yang tidak valid 4 soal (soal 17, 18, 19, 20) dengan rhitung terendah yaitu 0.697. Sesuai kriteria reliabilitas, maka dapat disimpulkan bahwa data butir soal yang valid mempunyai reliabilitas tinggi.

\section{KESIMPULAN}

Berdasarkan hasil penelitian dan pembahasan tentang pengembangan permainan tradisioanl Sepatu batok untuk pembelajaran penjasorkes di Sekolah Dasar, maka dapat disimpulkan sebagai berikut:

1) Permainan tradisional Sepatu batokmerupakan bahan alternatif untuk guru penjasorkes dalam memberikan materi permainan tradisional yang bertujuan agar siswa tidak melupakan permainan tradisional daerah mereka.

2) Permainan tradisional Sepatu batok dalam pembelajaran penjasorkes dapat meningkatkan aspek psikomotor, kognitif dan afektif berdasarkan hasil penelitian yang dilaksanakan di 2 SD yaitu keefektifan produk permainan tradisional Sepatu batok mendapat respon positif siswa dalam pembelajaran penjasorkes sebesar $97,46 \%$ sedang respon negative sebesar $2,53 \%$. Jadi kesimpulan keefektifan produk permainan tradisional sepatu batok dalam kategori sangatbaik.

3) Permainan tradisional sepatu batok dalam pembelajaran penjasorkes dapat dijadikan sebagai bahan alternatif guru dalam pelaksanaan pembelajaran berdasarkan hasil penelitian yang dilaksanakan di 2 SD yaitu hasil pengisian angket respon terhadap guru dianalisis dengan dipersentasekan dan diperoleh 
bahwa 92,5\% guru Penjasorkes memberikan respon positif dan 7,5\% memberikan respon negatifberarti guru Penjasorkes yang memberikan respon positif lebih dari $81 \%$ maka dapat dikategorikan bahwa respon guru Penjasorkes terhadap pengembangan permainan tradisional sepatu batok sebagai alternatif pembelajaran dalam kategori sangat baik.

4) Permainan tradisional sepatu batok dalam pembelajaran penjasorkes dapat meningkatkan denyut nadi siswa putri sebesar $68,60 \%$ dan siswa putra sebesar $69,16 \%$. jadi kesimpulan keterterimaan siswa terhadap permainan tradisional Sepatu batok dalam kategori sangat baik.

\section{DAFTAR PUSTAKA}

Achroni, Keen. (2012). Mengoptimalkan Tumbuh Kembang Anak Melalui Permainan Tradisional. Yogyakarta: Javalitera.

Depdiknas. (2003). Kurikulum 2004

Depdiknas. (2006). Kurikulum Satuan Pendidikan.

Depdikbud (1982) Permainan anak-anak daerah Lampung. Proyek inventarisasi dan dokumentasi kebudayaan daerah Lampung.

Masnur Muslich. (2008). KTSP Pembelajaran Berbasis Kompetensi dan Kontekstual. Jakarta: Bumi Aksara.

Pangrazi Robert P. (2004). Dynamic Physical Education Elementary School Children.San Fransisco. Benjamin Cummings.

Samsudin. (2008). Pembelajaran Pendidikan Jasmani Olahraga dan Kesehatan SD/MI. Jakarta: Litera

Samsudin. (2008). Pembelajaran Pendidikan Jasmani Olahraga dan Kesehatan SMP/MTS.Jakarta:LITERA PERNADA MEDIA GROUP

Slameto. (2003). Belajar dan Pembelajaran: PT Remaja Rosda Karya

Sukintaka. (2004). Teori Pendidikan Jasmani: Filosofi, pembelajaran, dan masa depan. Bandung: Penerbit Nuansa.

Susilana, R, dan Riyana, C. (2008). Media Pembelajaran Hakikat Pengembangan, Pemanfaatan dan Penilaian, Bandung: Jurusan Kurtepend FIP UPI.

Taga, (2003). Pendidikan Jasmani. Jakarta : Depdiknas Dirjen Dikdasmen.

Thomas K.T. Lee A.M, Thomas J.R. (2003) physical Education Methods for Elementary Teacher. Champain, IL. Human Kinetics. 
(2005). Undang - Undang Republik Indonesia Nomor 3 Tahun 2005

Tentang Sistem Keolahragaan Nasional. Jakarta : Kementrian Mempora.

Toho Cholik Mutphir (2004). Perkembangan Motorik Pada Masa Anak-Anak.

Jakarta: Proyek Pengembangan dan Keserasian Kebijakan Olahraga. Direktorat Jenderal Olahraga. Depdiknas.

Toho Cholik, Maksum, Ali. (2007). Sport Development Index. Jakarta : PT Indeks

Warsita. (2008). Teknologi Pembelajaran. Jakarta: Rineka Cipta

Wasis Dwiyogo. (2004). Konsep Penelitian dan Pengembangan. Makalah. Lokakarya Metodologi Penelitian Jurusan Kepelatihan Olahraga Fakultas IImu Keolahragaan, Universitas Negeri Semarang.

Widodo. (2004). Pengembangan Gerak Dasar Peserta Didik Kelas 1 dan 2 Sekolah Dasar (Usia 6-8 Tahun). Jakarta: Depdiknas, Pusat Pengembangan Kualitas Jasmani.

Yi Ching Huang. (2012). Physical Fitness and Academic Achievement of Elementary School Student. JPES 